\title{
Plastic Waste and the Environmental Crisis Industry
}

\author{
Oliver Smith ${ }^{1}$ Avi Brisman ${ }^{2,3,4}$
}

Accepted: 12 February 2021 / Published online: 16 March 2021

(c) The Author(s), under exclusive licence to Springer Nature B.V. part of Springer Nature 2021

\begin{abstract}
Our relationship with plastic is complex. While the societal benefits of plastic are undeniable, plastic has also come to occupy a central role within a culture of waste and disposable living that constitutes a significant problem for health and the natural environment. Public awareness of the harms asociated with plastic is high, thanks, in part, to a range of sustained media exposure. This, however, has so far failed to materialize in any significant global reduction in plastic pollution. Meaningful regulatory change that adressess the harms of plastic at the point of production is curiously absent, while some apparent gains have been rolled back-against a backdrop of a global pandemic and a rehabilitation of plastic. This article highlights the assemblage of media, government and corporate interests that performs the role of what we identify as the "Environmental Crisis Industry" ("ECI"), which perpetuates stasis in the face of environmental catastrphe. The ECI manages our anxieties through media discourses of precarity and danger, while at the same time, offering us attainable "solutions" that exist well within the logic of consumer capitalism-in effect, compelling us (at least morally) to become eco-consumers. In this way, the political energy of grassroots climate resistance is "pre-corporated," so to speak, into the product design of major corporations, dissipating the chance of real progressive change in favor of a new green spirit of capitalism.
\end{abstract}

\section{Introduction}

Since its invention, plastic has come to occupy a central position within our daily lives. While initially understood as inert and relatively harmless, decades of plastic waste, due to its innumerable uses, has resulted in a range of significant environmental problems. The properties that make it such a useful product, however, are also those that pose the greatest

Oliver Smith

oliver.smith@plymouth.ac.uk

1 School of Law, Criminology and Government, University of Plymouth, Plymouth, UK

2 School of Justice Studies, College of Justice and Safety, Eastern Kentucky University, Richmond, KY, USA

3 School of Justice, Faculty of Law, Queensland University of Technology, Brisbane, QLD, Australia

4 Newcastle Law School, Faculty of Business and Law, University of Newcastle, Callaghan, NSW, Australia 
challenges. Plastics are lightweight, hydrophobic and durable. We cannot seem to live without plastic, but its inability to break down means that pretty much every piece of plastic that has ever been produced, unless it has been incinerated, is still in existence today. Much of this plastic ends up in the environment (especially the marine environment), where it continues to decompose into ever-smaller particles, posing significant threats to plants and nonhuman animals and presenting challenges for collection and removal. The persistence of plastic in the environment means that it bioaccumulates in organisms and, over time, has the potential to disrupt food chains and delicate marine ecosystems, while continuing to pose uncertain threats to human health.

The central claim of this article is that the problem of plastic pollution-and our social and cultural orientation toward it - is influenced by the existence of an "Environmental Crisis Industry" (or "ECI"). As a result, meaningful change emerging from processes of tighter regulation on the production, use and disposal of plastic materials are ignored in favor of "solutions" that appear more palatable to state-corporate interests, and also to the global consumer classes, who fear disruption to their lifeworlds. After setting out some of the parameters of what we mean by the ECI, this article considers how the mainstream media's construction of plastic pollution, alongside the vortex of social media, magnify the intense and sometimes debilitating forms of anxiety in audiences, potentially destabilizing our previously unproblematic relationship with consumer culture. At this point, the ECI intervenes to generate a range of apparent solutions to the predicament that promise to assuage this anxiety and help us feel that we are helping to ameliorate the problem. As our relationship with existing consumer goods and brands becomes tarnished by their implication in environmental harm, the logic of the ECI demands that products be rebranded, marketed and repositioned in order to reassert our allegiance and brand confidence. Faced with the moral obligation to ditch our smartphone or abandon our favorite fast food drivethrough as a result of excessive plastic use, we grasp any opportunity to reconceive of these brands as ethical entities with the wellbeing of the planet at their core. This process reassures us that we can validate our consumer choices through identifying with the overarching image of the "eco-consumer"- a politicized, engaged and discerning individual. Consumer demands for government intervention are met by an array of minor adjustments to regulation and legislation, which place levies on plastic bag usage or prohibit microbeads from some forms of cosmetics. These are the low-hanging fruit and the easy wins that appeal to governments desperate to create the right optics and keep the engines of economic growth on the tracks, but nervous of (or about) instigating real change at a societal level. The ECI generates positive energy around the potential for human ingenuity in the form of technological progress to mitigate the harms of plastic use. In this sense, we are reassured and placated by the fiction that technology can solve the problems it creates.

\section{The Environmental Crisis Industry}

There is near universal acknowledgment that plastic waste is harmful, and yet, new uses for plastic are being realized all the time; meanwhile, the amount of new, virgin plastic being produced worldwide is increasing rather than decreasing (Taylor 2017). Despite the apparent global concern of the last few years, little systemic change is occurring in order to temper the harms of plastic pollution. Indeed, the recent enthusiastic zeal for environmental protection and the reduction of plastic pollution has been revealed as relatively tenuousrapidly eclipsed as other issues have emerged to monopolize our consciousness. Indeed, 
some governments utilized the cover of the global pandemic caused by the transmission of SARS-CoV-2, the virus that causes coronavirus disease 2019 (COVID-19), to roll back environmental protection (see, e.g., Paterson et al. 2020). Meanwhile, in this new era of social distancing and hyper-hygiene awareness, plastic producers have rushed to emphasize the aspetic properties of their products over paper or fabric alternatives (Tabuchi 2020). The emergence of the ECI is critical in understanding why so little is changing.

The ECI represents a convoluted and chaotic assemblage of media, government and corporate interests that epitomizes a neoliberal apparatus comprising political actors, corporations and organizations, aided and abetted by charities and career academics that, in combination, close the loop on the creation and absolution of the anxiety of inaction in relation to environmental crisis. In short, environmental crises generate anxiety through their depiction and framing across mainstream and social media. The horror with which viewers recoil at the stark imagery or heart-wrenching narratives on our screens, alongside broader stories of ecological collapse around global warming and climate change have, at their heart, the potential of political transformation - mobilization around an event so significant that it has the power to rupture the existing social order, creating the possibility for replacement with something new (Badiou 2005). This fissure in capitalism never fully emerges, of course, becoming instead filled by platitudinal low-level regulation of peripheral harms, such as the aforementioned microbeads in cosmetics or nominal levies on plastic bags. Into these cracks flow new ideas from above, exciting new products and marginally tweaked business models that assuage our concerns that something must be done(!!!) and allow us to continue our lives unhindered by the inconvenience of mass dissent.

To some extent, this comes as little surprise. Capital has a long history of commodifying its own dissent (e.g., Raymen and Smith 2016). The mantra of "there is no alternative" is broadly accepted as truth, internalized through what Mirowski (2013) terms "everyday neoliberalism." From time to time, a startling image or media report punctures the comfort of inertia. Rendered anxious and complicit by the images on our screens, we can vow never to buy a takeaway coffee without a reusable cup, to stop our profligate use of plastic bags or to purchase a bamboo toothbrush. Admiration from friends and family, and likes on social media, and so on serve to assure us that our actions are meaningful and that we are making a difference. The underpinning dynamics of global political economics that drive environmental crises, however, are rarely threatened; by shifting some of our consumer choices, we legitimize neoliberalism rather than threaten it, contributing to the growth of new markets based on a naïve belief in sustainability. While economic growth underpinned by the profit motive remains the cornerstone of the neoliberal economic form, meaningful environmental change is impossible.

\section{Consumerism and a Society of Waste}

There is little doubt that we live today in a consumer society. Consumer goods, services and experiences tether us to the central ideology of neoliberalism, functioning not only as markers of social class, as Veblen ([1899] 1965) noted over a century ago, but as symbolic props for "storying the self" (Hayward and Smith 2017). Through consumerism, we perceive the other, and our own view of our place in the world is mediated through the careful crafting and placement of commercials and social media (Kuldova 2016; see generally Brisman 2010, 2014). 
Our waking moments give no refuge from a constant onslaught of marketing designed to stimulate transient desires and engagement with a dizzying array of consumer goods that once promised to give satisfaction and which now tumble rapidly from favor to become shameful, obsolete junk, destined for landfills. New internet-based vectors of consumerism infiltrate our sleeping hours, too, resulting in a truly 24/7 cocoon of consumerism. Written into the scripts of consumerism are the need for items to offer something beyond the use value of the object. Consider, for a moment, the packaging of high-end consumer electronics. The process of revealing the latest incarnation of a phone or similar is, today, considered so titilating, sensuous and alluring in itself, that "unboxing" videos acquire huge numbers of views on social media (Mowlabocus 2020). With the emergence of a new consumer item, existing products instantly lose their luster and can rapidly become a source of humiliation. This ritualized discarding is cyclical, as each new item promises to satisfy our desires once it enters our possession, only to be replaced as new desires clamor in the vacuum. Indeed, often what we find most satisfying and enjoyable is not the actual capture of the object of our desires, but the desire for the object itself. This is why many people find the prolonged build-up to Christmas Day more enjoyable than the day itself. Consumer culture, as a system, is designed such that this truth is perpetually obscured. It encourages us to mis-locate our enjoyment and believe that it resides in the object itself, rather than in our desire for the object (McGowan 2016). The harms associated with this failure to locate the true source of our enjoyment are significant, manifesting as elevated levels of anxiety, depression and other forms of mental ill health (Hayward and Smith 2017).

The desire for these consumer goods and experiences is generated predominantly through marketing. Over the course of the last few decades, marketing has mutated from a fairly crude mechanistic model into one which draws on recent advances in technology to include an army of social influencers on social media, product placement in streamed television, algorithms to place advertisements on video-sharing websites and shopping sites, and so on (Gillespie and Joireman 2016). This constantly evolving process interacts with a range of human emotions to generate feelings of inadequacy and anxiety about, as well envy of and "fear of missing out" (FOMO), regarding a range of consumer goods and experiences, inputting into the system the little jolts of energy necessary to sustain forward motion in the shape of economic growth (Smith 2014). In this way, the marketing industry can be appreciated as integral to creating new and continuing forms of consumer identity, but at the same time, creating a generation of disaffected, post-political subjects. Traditional forms of identity, rooted in social class and shared biographies, are discarded and replaced with the "deracinated, depoliticised and cosmopolitan subject of consumerism" (Hall 2012: 375). Environmental crises, such as air and water pollution, biodiversity loss or climate change, ought to inspire in us such a level of crippling remorse that we disavow our attachment to harmful consumer goods and experiences. Instead, these emotions are brought into conflict with the contemporary re-orientated superego, which demands enjoyment and inflicts guilt for failing to take advantage of the various opportunities to enjoy ourselves within consumer capitalism (Raymen and Smith 2019a, b). The ECI, however, allows both of these competing superegos to co-exist and even become mutually reinforcing! In acknowledging the harms caused by plastic in the ocean, we do not have to renounce our enjoyment; we can, in fact, enjoy more - through alleviating guilt by consuming the products of the ECI, choosing to offset the carbon from our flights, and refusing a plastic straw in the departures lounge.

In an economic model that prioritizes symbolism, waste, itself, becomes symbolic. While we are familiar with the concept of conspicuous consumption (Veblen [1899] 1965; see generally Brisman 2009), it is perhaps time that we began thinking in terms 
of conspicuous waste as the symbolism of contemporary consumerism. Consumer items are discarded, becoming "waste," not because they are broken, damaged or defective, but because the functional materiality of the object is secondary to its consumer symbolism (Brisman and South 2013a, b, 2014, 2017a; Ferrell 2020). For generations, we have been able to ignore the fate of waste-to remain ignorant of its destination. In this cognitive vacuum, a culture of disposability has flourished, aided by a concerted onslaught of advertising from major corporations, who assure us that we deserve the time-saving benefits and convenience promised by a throwaway lifestyle. The days of naivety however, are over. China's refusal of Western garbage in 2018 brought rubbish back into view, piled up in stubborn heaps, as domestic recycling infrastructure failed immediately (McNaughton and Nowakowski 2019; see also Chua 2020; Dell 2019; Denne 2020; Humes 2019; Loria 2020: 31; Sullivan 2020; Zhong and Zhang 2019). ${ }^{1}$

Essentially, the harms relating to the production, consumption and disposal of plastic waste pose a range of threats to human health, nonhuman animal vitality and the environment, as a whole. The creation, consumption, use and disposal of plastic within society also contribute to broader and interrelated environmental crises of air and water pollution, biodiversity loss, and climate change. In the ensuing parts, we will examine how our understanding of the problem of plastic waste is framed by news and social media platforms, consumed and recirculated by us in ways that contribute to rising levels of eco-anxiety and problematic consumer identities, and repurposed to propel a limited and flawed array of proposed plastic solutions.

\section{Manufacturing (Eco-)Anxiety}

It is broadly acknowledged that the prolonged onslaught of sensory information with regard to the climate crisis is contributing to new forms of despair related to a sense of hopelessness and powerlessness (Clayton and Karazsia 2020; see generally Brisman 2020). This is not the objectless anxiety that characterizes life within the context of capitalist realism (Hall 2012; Smith and Raymen 2016), but a form of eco-anxiety which is nurtured primarily by the available information which corroborates our worst fears with regard to environmental crises. It is the grief of loss-the admission that extinction is a permanent state, that the changes brought about by biodiversity loss, by climate change, by extreme weather systems and events cannot be undone, and that the worst is yet to come (see Brisman and South 2020). It holds within it a realization that previously held certainties-such as access to clean water, a sustainable and self-perpetuating biosphere, reliance on the existence of power and safety from extreme weather events - can no longer be assured. This recognition has the capacity to instigate ontological insecurity - the loss of feeling of place in the world.

The relationship between anxiety and environmental crises is complex. Many of those that are already beginning to feel the impacts of disintegrating planetary systems are likely to experience clear emotional trauma at imminent dangers or the real effects of events such

\footnotetext{
1 According to Zhong and Zhang (2019), when China banned the import of plastic waste and other types of scrap into its country, it did so in the hopes that "recyclers would focus on processing domestic material instead." While this left American cities, in particular, scrambling for new locations that would receive its cardboard and plastic and other recyclables — and forced some such cities to end their recycling programsthe move also hurt a lucrative recycling business in China.
} 
as drought, flooding, heatwaves and hurricanes. These are acute effects, driven by fears of very real repercussions (Clayton and Karazsia 2020). Fear for our children in the event of a heatwave, for example, is real. Children and babies are less able to regulate their body temperatures and are more likely to succumb to heatstroke. In addition, the fragility of energy grids in even developed cities means that air conditioning and temperature-controlled environments are no guarantee of complete safety. For others, the loss of property, neighborhoods and irreplaceable possessions in the event of climate-driven disaster may invoke trauma (Clayton et al. 2017). For most, however-particularly those living in the Global North-anxiety can be more amorphous, coalescing within a maelstrom of other broad but indistinct forms of uncertainty and precarity that have come to define life within consumer capitalism (Hayward and Smith 2017). In this sense, for some, eco-anxiety is little more than simply one more nagging worry. Indeed, eco-anxiety can be harnessed as a driving factor in contemporary identity creation as evidenced by the burgeoning market in ecoconsumerism and the massive acceleration in social media content. In these cases, retweets and generation of content illustrating one's latest eco-purchase become a way of defining one's engagement - of showing that one cares. Maintaining a credible eco-identity takes hard work, and a commitment to eco-consumerism, which we examine in the paragraphs below.

One of the most popular documentaries of recent years, Blue Planet II, aired in 2017. The BBC Natural History Unit utilized the very cutting edge of technology to illuminate hidden recesses of the world's oceans, causing a global audience to marvel at the variety of life beneath the waves. Each year, the BBC Natural History Unit produces hours and hours of content with a natural history or wildlife theme, earning it a reputation for spectacular imagery of the natural world. Blue Planet II diverged from previous examples, with an explicit acknowledgment of the precarity of ocean life and, importantly, the role of humans in environmental degradation. This served as a corrective to the somewhat staged nature of previous BBC natural history films, criticized for airbrushing out the human impact on the ecosystems of the animals, faking natural environments and altering outcomes to fit a prime time narrative (Mendick and Malnick 2011). Perhaps one of the most evocative images of Blue Planet II was episode four's imagery of a pilot whale carrying its dead calf, which appeared to have died as a result of plastic pollution. The concluding episode of this series provided a cautionary note, highlighting the devastation wrought upon the ocean by climate change, plastic pollution and noise pollution, but notably closed with a note of optimism:

we are at a unique stage in our history. Never before have we had such an awareness of what we are doing to the planet, and never before have we had the power to do something about that, surely we have a responsibility to care for our blue planet. The future of humanity and indeed all life on Earth, now depends on us. [David Attenborough, Blue Planet II, S1, E7)]

Attenborough's commentary, here, places the future fate of the planet not with the plastic industry, not with governments, but with us as individuals (see generally Brisman 2013, 2017a, 2019a, b; Brisman and South 2017b) — a narrative both produced and utilized by the ECI to create new markets, assuage guilt and to guild an illusion of change so that nothing really has to.

For some, the popularity of Blue Planet II, and accompanying social media conversations, represents a significant watershed moment in the public discussion around climate change and plastic pollution. The way in which we consume media, however, is an important factor in explaining the underpinning feelings of anxiety which prompt particular 
forms of action. As Bernard Stiegler (2014) has pointed out, the rapid development of the internet as a platform for consuming popular culture has led to a homogenization of experience of what he refers to as "temporal objects," such as clips, movies, music and television shows. This results in a standardization of experience that he describes as a mass synchronization of consciousness and memory. Stiegler is not claiming that we all experience the same things in the same way, but that we encounter shared zones of experience. The way we experience media around a topic, such as plastic pollution, is filtered, and fragmented into staccato-like jolts of information that are delivered through countless methods and formats, but which share a monotonous similarity (Crary 2013). Across social media platforms, images, memes and stories are shared from a relatively small number of sources (Dean 2009). This is not the revolution in user-generated content that once promised a new electronic public sphere, but the surrender of these spaces to marketing.

Plastic pollution is a social problem that is set up perfectly for both mainstream and social media communication within the context of the ECI. In terms of television, the subject can grab the attention of an audience with ease (Jones et al. 2019). There is a clear, linear story to tell about a piece of plastic that ends up in the ocean and contributes to the death of a charismatic creature. There is no need for the careful explanations of complex data, of painstaking explorations of computer modeling, and of simulations that coverage of other environmental threats require. In the context of social media, the images of distressed or mutilated megafauna, the littered beaches and the plastic waste art (Cipolle 2020; Sligl 2018; https://storage.googleapis.com/gpuk-old-wp-site/press-releases/oceanplastic-sculpture-unveiled-central-london-20170327/index.html; https://www.underwater sculpture.com/; https://www.vanaqua.org/explore/exhibit-vortex; https://globalnews.ca/ video/4211472/douglas-coupland-holds-exhibit-on-plastic-pollution-at-vancouver-aquar ium)) are all eminently "retweetable." Furthermore, the simplicity of the solutions that are presented in relation to plastic pollution are appealing - easily reducible to a tweet, a meme or a hashtag. There is a clarity to the problem of plastic pollution that is not shared by other environmental crises. Indeed, Stafford and Jones (2019: 187) argue that:

plastic pollution has been overemphasized by the media, governments and ultimately the public as the major threat to marine environments at the expense of climate change and biodiversity loss... a convenient truth, especially as some mechanisms to reduce plastic waste play into corporate greenwashing in a neoliberal economy rather than addressing the root cause of overconsumption of resources.

These ecological marketing messages are delivered and processed by individuals in the same way as some of the most successful viral marketing campaigns across social mediaand for many of the same reasons (Gilroy-Ware 2017). Social media has become integral to contemporary iterations of identity, friendship and other peer bonds. Under the conditions of modernity, the limited social and geographic mobility resulted in relationships on a community and personal level that were deeper and perhaps more stable than many of today's "liquid" relationships (Bauman 2000). With the rise of social media, internetoptimists foretold of democratic spaces of tolerance and acceptance. The reality, however, has been much darker - a dystopian landscape of competitive individualism-of neoliberal narcissism unrestrained by physical boundaries. Rather than creating spaces of perfect information-sharing - of considered debate and broadening of our intellectual horizons, allowing us to engage fully in participatory forms of democracy-our use of internet technologies and, in particular, social media, is making us more stupid, generating feedback loops of stupidity and superficiality (see Carr 2010). 
Underpinning much of the potential for harm associated with social media is the pursuit of the recognition that comes with "friend requests," "follows" and "likes." For some, these associations are literally valuable, converted into revenue along with recognition as being an "influencer." For most, however, there is a more immediate benefit - the establishment of markers of identity. By carefully cultivating an online image through the retweeting of eco-virtuous behaviors, social media users are selectively presenting "who they are" through publication of idealized self-images. This is an easy route to presenting the self not only in a particular light—e.g., eco-aware-but in a way that serves to elevate the self in relation to other social media users. By sharing images of new eco-purchases or news stories about the latest green-tech, social media users are not rejecting the crass individualism that characterizes consumer capitalism; they are vehemently protecting it. As for the pervasive retweets of calls to action about plastic, these do not represent a cyberutopianism of eco-political will among the masses. For most, this is a simple form of clicktivism-a pejorative term that captures the interpassivity of habitually and monotonously clicking, liking and moving on within the sphere of social media (Kuldova 2018).

Much online activity is passive in nature, despite its appearance of connectivity, dynamism and energy. Posting a link, retweeting an image or commenting on a post are actions that we may think are active, but the vast majority of tweets or posts fails to carve out space for meaningful debate, instead quickly sinking into the void. Linking or reproducing content substitutes for proper engagement or commitment. For Dean (2009), the reduction of political engagement into incoherent fragments within the circulation of online content serves to perpetuate and reproduce the primacy of neoliberal technological infrastructure. Messages that initially bristle with political energy are diminished rapidly, hollowed out to exist as "intensities," to use Dean's (2009) term-indications of a subjective feeling. These "intensities" circulate within social media, drawing more similar content toward themmore comments, gifs, jokes and memes. The networks amplify the affect of the communication, notifications ping on the users' screen, and the tangle of affirmation, feedback and associated enjoyment works in place of the original political content. The problem or issue itself, however, continues unabated, despite the energy created and invested in the online space. This is not to say that the original poster does not care about the environmental issue at hand; rather, under communicative capitalism, online engagement often takes the form of a fetishistic disavowal that obfuscates, masks and conceals the true extent of political impotency. The political potential of the eco-tweet relies on the same networks that symbolically represent the dominance of neoliberalism. In this sense, social networks operate as an important part of the ECI.

The portrayal of environmental zeal underpinning many social media pronouncements appears to constitute a development in virtue signaling for those on the liberal left. Nagle (2017), in her searing account of online culture wars, outlines the growth of virtue signaling in the early days of Twitter. At this time, minor celebrities and fledgling social media stars noted that they were able to garner a significant number of retweets, likes and followers through pithily phrased comments, denouncing others in the public eye for perceived homophobia, racism, sexism, transphobia or xenophobia. This is a model that transfers neatly onto climate change and other environmental issues and provides further opportunities for Twitter users. The near total media domination of the Swedish teenager, Greta Thunberg, has led to a cascade of emulatory Twitter accounts. Any critique of Thunberg or the broader grassroots movements results in a new opportunity to collect online approval from the Twittersphere through acerbic attacks that position those trying to engage in debate as rabid right-wing climate change deniers. In these spaces, recognition and approval hold more currency than debate and learning. If we are to learn lessons from the 
relatively short history of the internet here, then it is that this is not going to end well. As Nagle (2017) points out, the first wave of virtue signalers, upon realizing that their online currency was being devalued by market saturation of like-minded users, began to turn on each other, with the end result being the fragmentation of any potential political progress.

\section{Plastic"Solutions"}

The global acknowledgment of the harms associated with plastic pollution signifies what, at first, appears to be a crisis point for capitalism that could be turned, repurposed and oriented toward a different way of doing things. Consumer capitalism is literally destroying the planet, perhaps irreversibly altering the world we inhabit at the geological level (Crutzen 2006; Zalasiewicz et al. 2017). The global responses to environmental threats, however, including that of plastic pollution, are entrenched within Fisher's (2009) capitalist realism - the inability of any collective imagination to see beyond the horizon of capitalism-the general adherence to the notion that there is no alternative. Capitalist realism is, as Fisher argues, characterized by a feeling of futility and entrapment-a "reflexive impotence" that disengages people from politics and cements them in a dull, repetitive cycle of consumption and anxiety. Through the ECI, however, we are offered safe passage through the darkness, as long as we submit to the symbolic fiction that we, as individuals, are responsible for the harmful effects of plastic waste within the environment. Through imagery of the detritus of our daily lives recognizably washed up on formerly pristine beaches, or being extracted from the bodies of marine wildlife, a clear link is drawn between our consumer behavior and a direct and visible harm, which contributes to a nagging feeling of guilt. The steady stream of imagery soon becomes a torrent, descending from multiple media channels.

\section{Eco-Consumerism}

For many coastal regions, especially in areas reliant on tourism, beach cleans have become a regular occurrence, and cities in the United Kingdom (UK) have fought among themselves to be the first to be recognized as plastic-free (Channon 2018). At the same time, a raft of environmental self-help books line the shelves of bookstores promising to assist us in transforming our lives in ten easy steps or offering us two-minute solutions that fit around our busy lives. Some of these are endorsed by celebrity environmentalists or CEOs; all of them place responsibility squarely at our door. Lucy Siegles' (2018) contribution is entitled Turning the Tide on Plastic: How Humanity (And You) can Make our Globe Clean Again. Martin Dorey's (2018) is called No. More. Plastic. What you can do to make a difference. Dorey (2018) is quick to assert that his book is apolitical, and centers on how small changes in consumer behavior, combined with spending two minutes picking up plastic each time you visit the beach, holds the secret to winning the "war on plastic." Of course, the central message of these books is political, rooted in an individualized ideology of responsibilization. These books and their authors are supported and promoted by a mainstream media, keen to locate positive news stories. The solutions provided within the books offer something more important than consumer advice; they offer a salve to the crippling anxiety, guilt and feelings of helplessness that are evoked by the overwhelming specter of environmental disaster, the continuous news of species extinction, rising sea levels and devastation of extreme weather events that flit across our news screens and populate 
our social media feeds. Responsibilization draws the focus away from the generative processes of consumer culture, toward our inability to consume ethically (see generally Brisman 2013). Nowhere are the producers of plastic, the large chemical companies that make up "Big Plastic," held accountable; nowhere is stringent regulation or reclassification of plastic as a toxic substance floated or considered. The result is the manufacturing of anxiety, guilt and shame. Our inability to consume properly, our inefficient recycling, our failure to engage in community beach cleans, and so on is transformed into a specific form of guilt which has an exchange value within the ECI, through the emergence of burgeoning green consumer markets.

Critical understandings of consumer society have long pointed out the significant and detrimental changes to our social fabric that occurred with the shift from an economy that served to satisfy basic needs through the conception and production of innovative products in increasingly efficient and convenient ways to one that produces commodities and lifestyles laden with cultural signifiers that function to convince consumers that their quality of life is constantly improving (Horkheimer and Adorno 2002). While proponents of consumer culture have framed consumer capitalism as bestowing freedom on individuals (see Douglas and Isherwood 1979), it must be acknowledged that the "freedom," such as it is, is critically limited to a degree of choice from an essentially meaningless menu (Adorno 2001). For Adorno (2001), the culture industry manipulates the population into wanting products that satisfy artificial desires, themselves created through the complex and increasingly sophisticated marketing and advertising industry. Through consumption, then, we are able to identify products and goods that speak for $u s$ - that help us reflect core aspects of our identities and project them onto the arenas of consumption. In return, we are rewarded for our cultural competence through recognition as cool, sophisticated individuals. Because these items are limited by the fact that they are mass-produced products of the culture industry, however, they offer only a form of pseudo-individualization, the parameters of which are dictated by what is available on the shelf (see Raymen 2019; Raymen and Smith 2020; Smith 2014). In the context of the newly anxious individual who is desperate to assert green consumer credential, the array of alternative products flooding the markets to replace harmful plastics comes as a huge relief. The pseudo-individualized green products - the "keep cups" (replacements for the disposable coffee cup), the bamboo straws, and so on-reflect these newfound green consumer credentials and offer the appearance of contributing to the solution to plastic waste without the individual having to make any real or challenging differences to their existing lifestyle.

The ECI also encompasses the large corporations that are orienting themselves rapidly toward the new appetite for eco-consumerism. Of course, this new iteration of consumerism could be interpreted as a form of resistance - of an indication that the new savvy consumers are politicized and not prepared to accept a marketplace flooded with unethical, environmentally harmful products. Consumerism, however, demands growth and, as such, has, at its heart, an ethos of waste which is completely at odds with goals of reducing emissions or simply producing less stuff. Hence, we see entire industries centering spectacular squandering and waste generation at the heart of their business model. Clothing giants, Primark and H\&M, originators of the "fast fashion" esthetic, Apple with its iPhones and iPads and IKEA with its cheap furniture-all create products loaded with symbolism that far outstretches their use value — and all with obsolescence built in. Baudrillard (1998: 46) described this as the "calculated "suicide; of the mass of objects, ... based on technological "sabotage" or organized obsolescence under cover of fashion." As the familiar objects in our possession become undesirable or no longer capable of inspiring envy in others, our 
desires move to the next purchase, leaving behind only waste, accumulating at an alarming rate.

In this context, then, it is naïve to believe that Corporate Social Responsibility (CSR) will drive change. Indeed, the CSR landscape is littered with incidences of corporate behemoths being dragged through the courts after failing to curtail their own harmful practices. For "Big Plastic," the recently-formed Alliance to End Plastic Waste (AEPW) is the mechanism through which CSR is enacted on a grand scale. Here, the major producers and manufacturers of plastics, including Dow Chemical, Exxon and PolyOne, assert their commitment to sustainability and clean oceans, pledging over US\$1billion over three years to the cause. Paid-for features in media outlets, such as National Geographic, and slick, pious videos underscoring the importance of the oceans, lend legitimacy to the commitment of industry to fixing the problems of plastic. For them, the answers (somewhat predictably) lie in increasing the recycling infrastructure, developing new technologies to repurpose waste, and educating governments and communities to "mobilize action" and to "clean up" existing plastic waste in the environment. Of course, donating to projects around these areas has the potential to increase profitability of the companies involved and augment their level of trust with consumers, as well as greenwashing more harmful business practices. Furthermore, it is important to note that none of these calls to action risk the profit margins of the companies involved. Some of the twenty-five companies whose names appear on the AEPW website (https://endplasticwaste.org/en/about) are the same companies who have been accused of gross environmental mismanagement, suppressing evidence of climate change and funding anti-environmental think-tanks. Moreover, the plastic producers who have committed to AEPW are all investing billions in the simulataneous expansion of plastic, building new plants to increase production of plastics in the coming years (Laville 2019).

Underpinning the success of consumerism and the predominant organizing factor in contemporary society is a huge marketing industry whose role is the creation of desire in consumer populations, embedding them in the psychic and cultural lives of individuals. One of the core demographics for marketers today is young people, and it is likely that this group will become increasingly important to the ECI, as marketing agencies vie to convert the zeal, idealism and enthusiasm of politically-awakened individuals into avid eco-capitalists. Marketing companies sell to children and young people the amorphous and indistinct, but, above all, desperately sought-after promise of "cool" individualized identities that guarantee to make one simultaneously stick out from the crowd and blend in (Miles 1998). The marketing industry is well-practiced in the utilization of contemporary icons who exude cool, and the symbolism of cool is, therefore, virtually transferred onto the objects for sale. Failure to engage in consumer markets is not perceived within these environs as a proto-political act of rebellion or dissent. It would serve only to label the individual as a "loser."

This is the overwhelming message of the past few decades, perpetrated on young people who, despite an increasing level of cynicism, have little resilience to such brutal forms of mass psychology. In this way, the brand becomes established as the primary "mirror of identification." Although we would expect to see our attachment to brands diminish with maturity, this is not the case (Smith 2014). In the absence of a strong symbolic order, narcissism and individualized egoism prevail, rather than being subsumed by a maturation of the political relationship between the individual and realty. Indeed, markets in home appliances, cars and clothing all testify to the capture of the individual in the world of brands, consumerism and symbolism-and the lingering, even rejuvenated, importance of brands to us as we grow older. 
We are seeing these processes unfold around us right now. For example, Apple drips vague claims of environmental responsibility into its social media advertising, asserting in an advertisement on Twitter that "during the final stages of assembly of an iPhone, no landfill waste is generated." Similarly, each iteration of an Apple product is portrayed as incrementally more environmentally-friendly than the last. Importantly, however, the overriding message is not to consume fewer Apple products but, somewhat paradoxically, that the ethical thing to do is to discard the old product and buy a new one, on the premise that it is less environmentally-damaging. Of course, these claims make little sense once we consider the harms associated with disposal of e-waste (Bisschop 2016; van Herk and Bisschop 2020), not to mention the environmental impact of mining more rare earth materials for the new machines (Brisman and South 2017a), alongside the energy required to package them and ship them around the world. Here, we see at work something more complex and perhaps more insidious than mere greenwashing. "Greenwash" tends to be the diversion of attention from ecologically-harmful business practices to instances of corporate environmental responsibility (albeit with minimal actual change and impact); engagement with the notion of sustainability, so perfectly illustrated by a commitment to a circular economy, can be a branding exercise that tunes in to the ecological zeitgeist in order to gain competitive advantage, while increasing sales, profits and making efficiency savings (Dauvergne and Lister 2013; Valenzuela and Böhm 2017).

Plastic waste, then, provides large corporations with a perceived problem that can be reoriented and positivized. As corporations fall over each other to commit to various reductions in plastic waste, they are seen by customers, media and shareholders in a positive light. Meanwhile, their inactions, omissions and shortcomings along the supply chain-or in any other aspect of their business operations - are framed not as lamentable failures, but as opportunities to further improve efficiency. In this sense, the language of sustainability is employed to embed the corporate brands in the eco-conscious of the consumer. For many companies, then, the issue of plastic waste provides them with the opportunity to react to ecological concern, with visible results, which tend to be lauded by the media as they are simple to visualize and report. By reducing waste through simple mechanisms, such as minimizing packaging or eliminating plastic straws, plastic waste is framed as manageable, and the product that was viewed previously as harmful or environmentally irresponsible, is reinvigorated and understood as green. Further criticism of the product or company is similarly addressed by incremental shifts "in the right direction," i.e., toward some stated desire for zero waste, no matter how improbable such a goal may be. As sustainability, zero waste, and commitment to a circular economy become normalized as business goals, the need for consumers to engage in radically different behavior (which would entail, inter alia, consuming less) is diminished. Instead, consumers need simply buy (and, in fact, buy more) from those companies that are adhering to the central tenets of "green growth." In other words, while "green consumption" may be a "flawed solution...because it perpetuates or even accelerates economic growth that is incompatible with a sustainable culture" (Grant 2011:245), many companies have doubled down on the message that we can consume our way out of the problem of plastic pollution.

We should greet positive news around increased levels of recycling and greater commitment to recycling targets from governments, corporations and institutions with a similar critical perspective. Of course, the allure of this solution is clear. If our plastic products can simply re-enter the production cycle, then the notion of their harmful wastefulness is reduced concomitantly. Again, it would appear that with only minor logistical considerations, a willing consumer base, some industry investment and some local-level or municipal logistics, incremental improvements on plastic capture could be a realistic solution. 
Moreover, public support for recycling provides a significant opportunity for corporate greenwash. Coca Cola's recent attempt to avert attention from the sheer volume of plastic waste it produces (Laville and Taylor 2017; McVeigh 2020) is a striking example. Coca Cola announced in 2017 that it would be increasing the content of recycled plastic (RPET) in its bottles to $50 \%$ by 2020 , and that it "plans to collect and recycle the equivalent of all the bottles and cans it uses by 2030" (Reed 2018 (emphasis added)). ${ }^{2}$ The decision to announce this target is part of a broader race for environmental credence within the major beverage producers, rather than being born of a genuine desire to reduce environmental impact, evidenced by the industry's history of vocal resistance to environmental issues which threaten profitability (Nace 2019). Furthermore, by committing to "sustainability," these companies receive the benefits of consumer goodwill without having to reduce their output, while at the same time, diverting attention from their culpability in childhood obesity, Type 2 diabetes, and accusations of water theft and contamination.

\section{Governance}

Although it would appear that there is some consumer support for recuding plastic use, evidenced by an increased commitment to recycling and a greater appetite for plastic alternatives, plastic production, is set to increase in the coming years, indicating that existing regulation on plastic is failing. Furthermore, new legislation ushered in by many countries across the globe is having a minimal impact, suggesting that the global governance of plastic pollution is set to become an important battle ground. As Dauvergne (2018) has pointed out, regulating plastic pollution is highly complex and is intensely variable across jurisdictional boundaries. In the Global South, for example, plastic production and consumption have outstripped the capacity of national infrastructure to manage waste streams. Global governance is weak, fragmented and inconsistent, while national policies vary in ambition and implementation. As such, most regulation is bottom-up, ad hoc and formed in the context of levels of acceptance and popularity, rather than targeted where it is most needed. These legislative interventions comprise the low-hanging fruit and the easy wins that governments hope will earn them green credentials without threatening their relationships with global producers of plastic. As a general rule, it would appear that the adoption of increased levels of governance around plastic takes place where corporate and popular resistance has been relatively low, while political gains and positive "optics" have been high.

Single-use plastics are a significant issue for plastic pollution, and the plastic straw and the plastic bag have become synonymous with the core problem. Around 8.5 million plastic straws are discarded annually in the UK (Raphelson 2018), while the global consumption of plastic carrier bags is estimated at $0.5-1$ trillion bags every year, or 1-2 million bags every minute (Nielsen et al. 2019). The response to the scourge of plastic bags has been relatively quick and appears wholly positive. Forty nations around the world have banned, restricted or taxed their use. The UK has enacted a 5p levy on plastic bags, outlawed microbeads in cosmetics (as mentioned at the outset of this article) and has born witness to celebrity endeavors to reduce plastic drinking straw usage. Such efforts, combined

\footnotetext{
2 Such a statement, on its surface, sounds impressive, until one realizes that the company is not promising to collect and recycle all of the bottles and cans that it produces-just the equivalent-meaning that many of the bottles and cans that it produces will wind up in landfills and sewer drains and elsewhere.
} 
with incentives from major coffee chains to reward customers who utilize their own reusable coffee cups, all seem to indicate the triumph of behavioral economics - the belief that if "nudged" in the right direction, consumers will make the ethical, responsible decision (Thaler and Sunstein 2008; see generally Zarnett 2020).

These purported solutions are problematic for two key reasons, however. First, they place the obligation for change (almost entirely) in the hands of the consumer, largely absolving the producers of plastic packaging and other disposable consumer items of responsibility. The actions required by the consumer are often either cost neutral or even represent cost savings for the company-and, more importantly, the company is still providing the customer with what he/she wants. Consider, for example, the ubiquitous street corner coffee chain. These companies create a miniscule inducement or reward to consumers who do not use a disposable cup, but are careful not to alienate those who do. By apparently taking a stand against the threat of plastic, they earn valuable public relations coverage, diverting public ire from their offshore tax structures, inequitable supply chains, unfair labor practices or aggressive corporate cultures; but by falling short of eliminating their use of plastic, the impact of their actions is negligible.

Second, these "solutions" serve predominantly to assuage the eco-anxiety generated by relentless exposure to evidence of the devastating impacts of plastic on the natural world. Overwhelmed, on some level, we sense that environmental challenges, such as marine plastics, are complex and global in their causes, but feelings of powerlessness threaten to deepen the spiral of eco-despair. As such, we are grateful for the opportunity within the workings of capitalism to do something, even if we know on some level that it is not enough.

Furthermore, it is important to remember that the adoption of seemingly progressive regulation around plastic use has the potential to unleash a raft of unintended consequences, with the capacity to generate harm and exacerbate existing inequalities. A handful of African states, including Kenya and Rwanda, are lauded as examples of successful implementations of a plastic bag ban. There are, however, a number of negative impacts surrounding the ban that illustrate the complexity of apparently simple regulatory action. The ban on the manufacture, sale and use of plastic bags in both countries comes with significant penalties, although the polypropylene bags that are offered as legal, reusable alternatives are often poor quality and break easily (Mbugua 2020). Biodegradable bags fare no better (Napper and Thompson 2019). Local demand has driven a thriving black market in plastic bags smuggled across the border from neighboring countries, with the (predominantly female) smugglers risking arrest and beatings (Nyirabihogo 2015). The ban also disproportionately affects poorer traders and consumers. While larger stores are able to absorbs some of the costs associated with the ban, low-level street vendors rely on the small plastic bags to package their goods. Many items are sold in single servings-a cup of cooking oil or a handful of washing powder - to customers who earn less than a dollar a day (Oyake-Ombis 2017).

These unintended consequences are evident across the globe. In the UK, the plastic bag levy appeared to be a resounding success: following its introduction in 2017 , the 5 p charge was heralded with cutting use in supermarkets by $86 \%$. On closer inspection, however, these gains were largely canceled out by the massive increase in sales of the thicker "bags for life," which are more resource intensive to produce and no less environmentally harmful upon entering the waste stream (Gabbatiss 2018).

This lack of meaningful change at a global level will not be altered by increasing levels of public awareness, nor by cajoling consumers into using alternative items in some corners of the market. The stasis of effective governance is maintained by an increasingly 
powerful industry that is fiercely resistant to regulation in every country across the globe. While some jurisdictions appear to be making headway in reducing some forms of plastic waste, the global plastics industry navigates a patchwork of legislative changes, developing more types of plastic and expanding into new markets at a pace far exceeding regulatory oversight. Here, the ECI operates in full view, as "Big Plastic" steers a course toward market-based solutions that champion corporate self-regulation and consumer responsibility, while closing off avenues that might lead to effective change.

\section{Technosalvation}

The idea that human ingenuity will provide us with new forms of technology that counter the impact of environmental crises in the nick of time is a seductive one (see, e.g., Zarnett 2020). The belief in a linear progression of the human endeavor is a central tenet of Enlightenment thinking and, as a species, we have a long history of technological innovation and a proven capacity for paradigmatic change off the back of rapid shifts in technology (Brisman 2015). The belief that the tide of technology lifts all boats is pervasive, despite indications that it is overstated. The development of information technologies, for example, has not led to a period of further innovation for the progression of the human endeavor (Dean 2009). Instead, we have seen a hollowing out of meaningful labor, and technologies weakening workplace security through the creation of the gig economy, as demonstrated by companies such as Uber or Deliveroo. Control of the internet, rather than its development, has been the focus of business, which has seen the majority of traffic fall into the hands of an astonishingly small number of men. These are not developments that spark innovation and transformative politics. The degree to which we are capable of imagining alternate futures is diminishing rapidly, with any meaningful progress being subsumed into the capitalist realism that dictates a meek acquiescence to the primacy of capitalism. Despite this, the new vectors of information control and dissemination are efficient in creating a narrative of progress, parading new products and technologies into our consciousness, just enough to convince us that things are heading in the right direction. This has given rise to an acknowledgment of environmental crises as an unintended consequence of technological development, but also an unshakeable belief that technology will provide the solution to the problems it has caused.

Many of the placatory assertions that technology will provide solutions to environmental problems have their origin in neoclassical economics - the all-pervasive but myopic underpinning of much economic thought-rooted steadfastly in the belief of the existence of the rational individual and a dogmatic attachment to the pursuit of economic growth. Here, the Gross Domestic Product (GDP) is held as a measure of successful economic activity, synonymous with wellbeing and social progress. The result is debilitating for almost any discussion about the environment across the social sciences, which instantly becomes drawn toward a starting point of accepting market exchange models of society as immutable. Within this environment, nature is viewed as a form of capital, and pollution becomes a commodity to be traded on the open market. Put simply, the space for new ideas and progressive thought is minimal. This has seen the confinement of responses to environmental crises to a range of policies and initiatives that do not stray too far from "business as usual." The seduction of the technological solution lies in the promise that the negative effects of plastic pollution can be countered without any requirement to reconsider our engagement with or relationship to consumer capitalism. In effect, it is an invitation to carry on as if nothing has to change, which effectively diverts attention and urgency from 
the problems caused by the ways in which we consume plastic. Without addressing the generative forces and structural processes which underpin contemporary society, advances in science and technology will ultimately serve the existing values of economic growth and related forms of individualization and atomization, accelerating us toward collapse (Huesemann and Huesemann 2011).

\section{Conclusion}

Plastic is perhaps the defining material of consumer society, and one which has become synonymous with waste. While it has undoubtedly become an indispensable material across a range of industries - from aviation to construction to health care-its relationship to a consumer culture predicated on instant gratification, convenience and disposability has embedded an addiction to single-use plastic, underpinning a throwaway culture that has contributed to one of the prevailing environmental crises of our era. The harms associated with plastic waste are planetary in scale, impacting some of the most delicate ecosystems and the most remote locations on Earth. In recent years, public awareness around the harms of plastic has increased significantly, and yet there is little indication that the damage wrought by plastic waste is receding. This article has attempted to highlight one component of our society that is responsible for this stasis in the face of significant environmental harm. The ECI generates anxiety and guilt through news reporting, mainstream media framing and social media engagement while, at the same time, guiding us toward a range of solutions that serve to protect capital and generate profit. What will happen in the coming months and years is, of course, uncertain, particularly as we emerge tentatively from the social, economic and health effects of a global pandemic. The planet appeared to breathe a sigh of relief as flights were grounded, industry slowed and cars remained parked on driveways during the COVID-19 lockdown of 2020 (see, e.g., Biswas 2020; Bond et al. 2020; Cooper 2020; Crist 2020; Gardiner 2020; Le Quéré et al. 2020; Mohm 2020; Plumer and Popovich 2020; Schwartz 2020; Simpkins 2020; Stone 2020; Zarnett 2020). The demand for plastic, however, seems not to have diminished. In fact, plastic bags, packaging and other indications of the culture of disposability shifted rapidly from stigmatized products to (false) guarantees of sterility, cleanliness and hygiene (e.g., Chua 2020; Diller 2020; Noel and Kew 2020; van Doremalen et al. 2020). At the same time, pubs and restaurants hurriedly erected countless Perspex screens, to reduce droplet transmission and to enable a return to trading as soon as possible.

It is possible that a different political landscape will begin to emerge-one in which the natural world is prioritized. As such, the ECI will need to be repurposed, generating not guilt or anxiety at the fate of the planet, but permission to imagine alternative, more equitable futures. The paper-thin corporate commitment to the Black Lives Matter movement (see, e.g., Jan et al. 2020), however, is a curt reminder that underpinning the interactions of global corporations and the world around them is a commitment to the profit motive, and an unerring desire to maintain a populace of fragile, desiring individuals. Global responses to COVID-19 have illustrated the potential of socialist policies, but as Harvey (2020) has noted, if recovery from crisis requires adoption of economic socialism, then those who control the flow of global finance will work to ensure that we experience national socialism rather than a socialism centered on people or the environment. Even if governments take this opportunity to invest in green economic recovery, any progress on the problem of plastic is likely to be sacrificed quickly. Indeed, for the plastic producers, these are boom times: 
for most applications, alternatives to plastic are not sufficiently cost-effective to produce at scale and, in the short term, at least, "Big Plastic" will endeavor to regain its place, if not in our affections, then at least in our lives. The ECI, in its current form, is integral to achieving this goal. For the time being, depressed oil prices mean that it is cheaper to produce new plastics than it is to recycle (Sullivan 2020), and the global demand for plastic ensures the continuation of harmful emissions as a result of the industrial processes involved, as well as creating more single-use plastic that will eventually end up in the marine environment. Of course, for the consumer, maintaining eco-identities is still desirable and still possible, with plastic-related transgressions being forgiven in these uncertain times. Plastic use in a COVID-19 context is now framed and perceived as socially responsible, and also excused as a temporary blip in an otherwise flawless green identity, while the market for green alternatives here and elsewhere continues to grow. For our hopes of addressing plastic pollution in any meaningful way, then, the future looks bleak. The new normal is a future where our environmentalism comes plastic wrapped and disposable, against a backdrop of rising unemployment, precarity and a growing array of environmental crises.

\section{References}

Adorno, T.W. (2001). The culture industry: Selected essays on mass culture. London. Routledge

Badiou, A. (2005). Being and Event. New York: Continuum.

Baudrillard, J. (1998). The Consumer Society: Myths and Structures. London: Sage.

Bauman, Z. (2000). Liquid Modernity. Cambridge: Polity Press.

Bisschop, L. (2016). How E-Waste Challenges Environmental Governance. In T. Wyatt (Ed.), Hazardous Waste and Pollution: Detecting and Preventing Green Crimes (pp. 27-44). Cham, CH: Springer.

Biswas, S. (2020). India coronavirus: Can the Covid-19 lockdown spark a clean air movement? BBC News, Apri 21. Retrieved on February 11, 2021, from https:/www.bbc.com/news/world-asia-india-52313 972.

Bond, A.J., Morrison-Saunders, A., Retief, F.P., \& Doelle, M. (2020). Environmental regulations likely to be first casualties in post-pandemic recovery. The Conversation, May 15. Retrieved on February 11, 2021, from https://heconversation.com/environmental-regulations-likely-to-be-first-casualties-inpost-pandemic-recovery-137941.

Brisman, A. (2009). It Takes Green to Be Green: Environmental Elitism, "Ritual Displays," and Conspicuous Non-Consumption. North Dakota Law Review, 85(2), 329-70.

Brisman, A. (2010). 'Creative Crime' and the Phytological Analogy. Crime Media Culture, 6(2), 205-25.

Brisman, A. (2013). Not a Bedtime Story: Climate Change, Neoliberalism, and the Future of the Arctic. Michigan State International Law Review, 22(1), 241-89.

Brisman, A. (2014). In the Garden with "Creative Crime": Kudzu and the Third Branch. In M. H. Jacobsen (Ed.), The Poetics of Crime: Understanding and Researching Crime and Deviance Through Creative Sources (pp. 51-70). Surrey, UK: Ashgate.

Brisman, A. (2015). Environment and conflict: A typology of representations. In A. Brisman, N. South, \& R. White (Eds.), Environmental crime and social conflict: Contemporary and emerging issues (pp. 285-311). Surrey, UK: Ashgate.

Brisman, A. (2019a). The fable of the three little pigs, climate change and green cultural criminology. International Journal for Crime, Justice and Social Democracy, 8(1), 46-69. https://doi.org/10.5204/ ijcjsd.v8i1.470.

Brisman, A. (2019b). Stories of Environmental Crime, Harm and Protection: Narrative Criminology and Green Cultural Criminology. In J. Fleetwood, L. Presser, S. Sandberg \& T. Ugelvik (Eds.), The Emerald Handbook of Research in Narrative Criminology (pp. 153-72). Bingley, West Yorkshire, UK: Emerald Group Publishing.

Brisman, A. (2020). Cultural criminology and narrative criminology's shared interests. More than just criminological verstehen. Tijdschrift over Cultuur \& Criminaliteit, 10(3), 14-34. https://doi.org/10.5553/ TCC/221195072020010003002.

Brisman, A., \& South, N. (2013a). Conclusion: The planned obsolescence of planet earth? How green criminology can help us learn from experience and contribute to our future. In N. South \& A. Brisman 
(Eds.), Routledge International Handbook of Green Criminology (pp.409-17). Abingdon, Oxon, UK: Routledge.

Brisman, A., \& South, N. (2013b). A green-cultural criminology: An exploratory outline. Crime Media Culture, 9(2), 115-135.

Brisman, A., \& South, N. (2014). Green Cultural Criminology: Constructions of Environmental Harm, Consumerism, and Resistance to Ecocide. Abingdon, Oxon, UK: Routledge.

Brisman, A., \& South, N. (2017a). Consumer technologies, crime and environmental implications. In M.R. McGuire \& T. J. Holt (Eds.), The Routledge Handbook of Technology, Crime and Justice (pp. 310-24). Abingdon, Oxon: Routledge.

Brisman, A., \& South, N. (2017b). Green cultural criminology, intergenerational (in) equity and "life stage dissolution" In M. Hall, J. Maher, A. Nurse, G. Potter, N. South, \& T. Wyatt (Eds.), Greening criminology in the 21st century: Contemporary debates and future directions in the study of environmental harm (pp. 219-232). Surrey: Ashgate.

Brisman, A., \& South, N. (2020). A criminology of extinction: Biodiversity, extreme consumption and the vanity of species resurrection. European Journal of Criminology, 17(6), 918-935. https://doi. org/10.1177/1477370819828307.

Carr, N. (2010). The Shallows: How the Internet Is Changing the Way We Think, Read and Remember. London: Atlantic Books.

Channon, M. (2018). Plymouth is now the UKs first Plastic-Free city. Plymouth Live, June 8. Retrieved on December 11, 2020, from https://www.plymouthherald.co.uk/news/plymouth-news/plymouthnow-uks-first-plastic-1652327.

Chua, J. M. (2020). Plastic bags were finally being banned. Then came the pandemic. Vox. May 20. Retrieved on February 11, 2021, from https://www.vox.com/the-goods/2020/5/20/21254630/plast ic-bags-single-use-cups-coronavirus-covid-19-delivery-recycling.

Cipolle, A. V. (2020). A Plastic Menagerie. The New York Times, March 13: F8. Published online as "When the Ocean Gives You Plastic, Make Animals," on March 9, 2020, at https://www.nytimes. com/2020/03/09/arts/design/ocean-plastic-sculpture.html.

Clayton, S., Manning, C. M., Krygsman, K., \& Speiser, M. (2017). Mental Health and Our Changing Climate: Impacts, Implications, and Guidance. Washington, D.C.: American Psychological Association and ecoAmerica.

Clayton, S., \& Karazsia, B. T. (2020). Development and validation of a measure of climate change anxiety. Journal of Environmental Psychology, 69(June), 101434. https://doi.org/10.1016/j.jenvp. 2020.101434.

Cooper, D. (2020). Nature is Still in Charge. The Cumberland, May/June: 11.

Crary, J. (2013). 24/7: Late Capitalism and the Ends of Sleep. London: Verso.

Crist, M. (2020). What the Pandemic Means for Climate Change. The New York Times, March 29: SR4. Published online as "What the Coronavirus Means for Climate Change" on March 27, 2020, at https://www.nytimes.com/2020/03/27/opinion/sunday/coronavirus-climate-change.html.

Crutzen, P. J. (2006). The "Anthropocene." In Ehlers, E., \& Krafft, T. (Eds.), Earth System Science in the Anthropocene (pp. 13-18). Springer, Berlin, Heidelberg. https://doi.org/10.1007/3-540-26590-2_3.

Dauvergne, P., \& Lister, J. (2013). Eco-business: A big-brand takeover of sustainability. Cambridge, MA. The MIT Press.

Dean, J. (2009). Democracy and Other Neoliberal Fantasies. Durham, NC: Duke University Press.

Dell, J. (2019). 157,000 Shipping Containers of U.S. Plastic Waste Exported to Countries with Poor Waste Management in 2018. Plastic Pollution Coalition, March 6. Retrieved on February 11, 2021, from https://www.plasticpollutioncoalition.org/blog/2019/3/6/157000-shipping-containersof-us-plastic-waste-exported-to-countries-with-poor-waste-management-in-2018.

Denne, L. (2020). Coronavirus pandemic threatens to undo progress on plastic pollution. NBC News, May 15. https://www.nbcnews.com/science/environment/coronavirus-pandemic-threatens-undoprogress-plastic-pollution-n1207231.

Diller, N. (2020). Santa Claus Is Coming To Town . . . In Plastic Bubbles And Sociall Distant Sleighs. National Public Radio (NPR), December 4. Retrieved on February 11, 2021, from https://www. npr.org/local/305/2020/12/04/943150770/santa-claus-is-coming-to-town-in-plastic-bubbles-andsocially-distant-sleighs.

Dorey, M. (2018). No. More. Plastic. What you can do to make a difference. London: Penguin Books.

Douglas, M., \& Isherwood, B. (1979). The World of Goods. London: Routledge.

Ferrell, J. (2020). Consumed by the Crisis: Green criminology and cultural criminology. In A. Brisman $\&$ N. South (Eds.), Routledge International Handbook of Green Criminology (2nd ed). London. Routledge.

Fisher, M. (2009). Capitalist Realism. Winchester, UK: Zero Books. 
Gabbatiss, J. (2018). Over 1 million 'bags for life' sold undermine government efforts to refuce plastic waste. Independent, December 26. Retrieved on December 11, 2020, from https://www.indep endent.co.uk/environment/plastic-bag-for-life-waste-5p-charge-michael-gove-iceland-tesco-pollu tion-a8699441.html.

Gardiner, B. (2020). Pollution made COVID-19 worse. Now lockdowns are clearing the air. National Geographic, April 8. https://www.nationalgeographic.com/science/2020/04/pollution-made-thepandemic-worse-but-lockdowns-clean-the-sky/.

Gillespie, B., \& Joireman, J. (2016). The role of consumer narrative enjoyment and persuasion awareness in product placement advertising. American Behavioral Scientist, 60(12), 1510-1528.

Gilroy-Ware, M. (2017). Filling the void: emotion, capitalism and social media. London. Repeater Books

Grant, L. K. (2011). Can we consume our way out of climate change? A call for analysis. The Behavior Analyst, 34(2), 245-266.

Hall, S. (2012b). Theorizing Crime and Deviance: A New Perspective. London: Sage.

Harvey, D. (2020). Anticapitalist politics in the time of Covid-19. March 19 [Revised March 20]. Retrieved on December 11, 2020, from http://davidharvey.org/2020/03/anti-capitalist-polit ics-in-the-time-of-covid-19/.

Hayward, K., \& Smith, O. (2017). Crime and Consumer Culture. In A. Liebling, S. Maruna, \& L. McAra (Eds.), The Oxford Handbook of Criminology (6 $6^{\text {th }}$ ed.) (pp.306-28). Oxford: Oxford University Press.

Horkheimer, M., \& Adorno, T.W. (2002). Dialectic of Enlightenment. Stanford, CA: Stanford University Press.

Huesemann, M., \& Huesemann, J. (2011). Techno-fix: why technology won't save us or the environment. Gabriola Island, BC: New Society Publishers.

Humes, E. (2019). You Can't Recycle Garbage. Sierra Magazine, 104(4) [July/August], 24-28, $30,42$.

Jan, T., McGregor, J., Merle, R., \& Tiku, N. (2020). As big corporations say 'Black Lives Matter', their track records raise scepticism. The Washington Post, June 13. Retrieved on December 11, 2020, from https://www.washingtonpost.com/business/2020/06/13/after-years-marginalizing-blackemployees-customers-corporate-america-says-black-lives-matter/?arc404=true.

Jones, J. P., Thomas-Walters, L., Rust, N. A., \& Veríssimo, D. (2019). Nature documentaries and saving nature: Reflections on the new Netflix series Our Planet. People and Nature, 1(4), 420-425.

Kuldova, T. (2016). Directing Passions in New Delhi's World of Fashion: On the Power of Ritual and 'Illusions Without Owners'. Thesis Eleven, 133(1): 96-113.

Kuldova, T. (2018). Interpassive Phenomena in Times of Economic Subordination. Continental Thought and Theory, 2(1), 32-49.

Laville, S. (2019). Coca-Cola admits it produces $3 \mathrm{~m}$ tonnes of plastic packaging a year. The Guardian, March 14. Retrieved on December 11, 2020, from https://www.theguardian.com/business/2019/ mar/14/coca-cola-admits-it-produces-3m-tonnes-of-plastic-packaging-a-year.

Laville, S., \& Taylor, M. (2017). A million bottles a minute: World's plastic binge 'as dangerous as climate change'. The Guardian, June 28. Retrieved on December 11, 2020, from https://www.thegu ardian.com/environment/2017/jun/28/a-million-a-minute-worlds-plastic-bottle-binge-as-dange rous-as-climate-change.

Le Quéré, C., Jackson, R.B., Jones, M.W., Smith, A.J.P., Abernethy, S., Andrew, R.M., De-Gol, A.J., Willis, D.R., Shan, Y., Canadell, J.G., Friedlingstein, P., Creutzig, F., \& Peters. G.P. (2020). Nature Climate Change, 10(May 19), 647-653. https://doi.org/10.1038/s41558-020-0797-x.

Loria, K. 2020. Think You Don't Eat Plastic? Consumer Reports, 8(6) [June]: 26-35. Available at: https://www.consumerreports.org/health-wellness/how-to-eat-less-plastic-microplast ics-in-food-water/.

McGowan, T. (2016). Capitalism and desire: The psychic cost of free markets. New York. Columbia University Press.

McNaughton, S., \& Nowakowski, K. (2019). How China's plastic waste ban forced a global recycling reckoning. National Geographic, June. Retrieved on December 11, 2020, from https://www.nationalge ographic.com/magazine/2019/06/china-plastic-waste-ban-impacting-countries-worldwide/.

Mendick, R., \& Malnick, E. (2011). BBC accused of routine 'fakery' in wildlife documentaries. The Telegraph, December 18. Retrieved on December 11, 2020, from https://www.telegraph.co.uk/cultu re/tvandradio/bbc/8963053/BBC-accused-of-routine-fakery-in-wildlife-documentaries.html.

Miles, S. (1998). Consumerism: A Way of Life. London: Sage.

Mirowski, P. (2013). Never let a serious crisis go to waste: How neoliberalism survived the financial meltdown. London: Verso Books. 
Mohm, T. (2020). The Traffic Trade-Off. The New York Times, June 5: A9. https://www.nytimes.com/ 2020/06/04/climate/coronavirus-traffic-air-quality.html.

Mowlabocus, S. (2020). 'Let's get this thing open': The pleasures of unboxing videos. European Journal of Cultural Studies, 23(4), 564-579. https://doi.org/10.1177/1367549418810098.

Mbugua, S. (2020). Two years ago, Kenya set the world's strictest plastic bag ban. Did it work? Huffpost, January 23. Retrieved on December 11, 2020, from https://www.huffingtonpost.co.uk/entry/plast ic-bag-ban-works-kenya_n_5e272713c5b63211761a4698?ri18n=true.

McVeigh, K. (2020). Coca-Cola, Pepsi and Nestlé named top plastic polluters for third year in a row. The Guardian, December 7. Retrieved on February 7, 2021, from https://www.thegu ardian.com/environment/2020/dec/07/coca-cola-pepsi-and-nestle-named-top-plastic-pollu ters-for-third-year-in-a-row.

Nace, T. (2019). Coca-Cola Named The World's Most Polluting Brand in Plastic Waste Audit. Forbes, October 29. Retrieved on December 11, 2020, from https://www.forbes.com/sites/trevornace/2019/ 10/29/coca-cola-named-the-worlds-most-polluting-brand-in-plastic-waste-audit/\#5b01850a74e0.

Nagle, A. (2017). Kill all normies: Online culture wars from 4chan and Tumblr to Trump and the altright. Alresford, Hants, UK: Zero Books

Napper, I., \& Thompson, R. (2019). Environmental Science \& Technology 53(9), 4775-4783. https://doi. org/10.1021/acs.est.8b06984.

Nielsen, T. D., Holmberg, K., \& Stripple, J. (2019). Need a bag? A review of public policies on plastic carrier bags - Where, how and to what effect? Waste Management, 87, 428-440.

Noel, A.M., \& Kew, J. (2020). 2020. Single-Use Plastics Make a Comeback on Pandemic Fears. Bloomberg Green, May 1. Retrieved on February 11, 2021, from https://www.bloomberg.com/news/artic les/2020-05-01/single-use-plastics-like-polystyrene-make-a-comeback-in-pandemic?sref=dYPvZ Qvk.

Nyirabihogo, N. (2015). Rwandan women see smuggling plastic bags as path to greater income. Global Press Journal, September 27. Retrieved on December 11, 2020, from https://globalpressjournal.com/ africa/rwanda/rwandan-women-see-smuggling-illegal-plastic-bags-as-path-to-greater-income-despi te-risk-of-arrest/.

Oyake-Ombis, L. (2017). Kenya should be focussing on recycling, not banning plastic bags. The Conversation, July 4. Retrieved on December 11, 2020, from https://theconversation.com/kenya-shouldbe-focused-on-recycling-not-banning-plastic-bags-79679.

Paterson, J., Devine, B., \& Mordecai, G. (2020). Rolling back Canadian environmental regulations during coronavirus is short-sighted. The Conversation, June 14. Retrieved on December 11, 2020, from https://theconversation.com/rolling-back-canadian-environmental-regulations-during-coron avirus-is-short-sighted-139636.

Plumer, B., \& Popovich, N. (2020). Traffic and Pollution Plummet as U.S. Cities Shut Down for Coronavirus. The New York Times, March 22. Retrieved on February 12, 2021, from https://www.nytimes. com/interactive/2020/03/22/climate/coronavirus-usa-traffic.html

Raphelson, S. (2018). "In Thailand, 17 Pounds Of Plastic Kills Whale, Highlighting Ocean Pollution." National Public Radio (NPR): Here \& Now, June 6. Retrieved on December 11, 2020, from https://www.npr.org/2018/06/06/617213676/in-thailand-17-pounds-of-plastic-kills-whale-highl ighting-ocean-pollution.

Raymen, T., \& Smith, O. (2016). What's Deviance Got to Do with It? Black Friday Sales, Violence and Hyper-Conformity. The British Journal of Criminology, 56(2): 389-405.

Raymen, T. (2019) Lifestyle Gambling in Accelerated Culture. In T. Raymen \& O. Smith (Eds.), Deviant Leisure: Criminological Perspectives on Consumerism and Harm (pp.259-82). Basingstoke, Hampshire, UK: Palgrave Macmillan.

Raymen, T., \& Smith, O. (2020). Gambling and Harm in 24/7 Capitalism: Reflections from the Post-Disciplinary Present. In S. Hall, T. Kuldova, \& M. Horsley (Eds.), Crime, Harm and Consumerism. Abingdon, Oxon, UK, and New York: Routledge.

Raymen, T., \& Smith, O. (2019a). The Deviant Leisure Perspective: A Theoretical Introduction. T. Raymen \& O. Smith (Eds.), Deviant Leisure: Criminological Perspectives on Consumerism and Harm (pp.17-44). Basingstoke, Hampshire, UK: Palgrave Macmillan.

Raymen, T., \& Smith, O. (2019b). Deviant Leisure: A Critical Criminological Perspective for the $21^{\text {st }}$ Century. Critical Criminology: An International Journal, 27(1), 115-130. https://doi.org/10.1007/ s10612-019-09435-x.

Reed, S. (2018). Brick by brick: Lego's search for non-petroleum-based alternative. The Irish Times, September 8. Retrieved on December 11, 2020, from https://www.irishtimes.com/life-and-style/ health-family/parenting/brick-by-brick-lego-s-search-for-non-petroleum-based-alternative- 1 . 3620788 . 
Schwartz, J. (2020). Precautions Taken Because of Virus Help to Fight Climate Change, Too. The New York Times, March 17: A7. Published online as "Social Distancing? You Might Be Fighting Climate Change, Too" on March 13, 2020, at https:/www.nytimes.com/2020/03/13/climate/coronavirus-habits-carbon-footprint.html.

Siegle, L. (2018). Turning the Tide on Plastic: How Humanity (And You) Can Make Our Globe Clean Again. London. Hachette UK.

Simpkins, G. (2020). COVID-19 carbon cuts. Nature Reviews Earth \& Environment, 1(May 19), 279. https://doi.org/10.1038/s43017-020-0062-x.

Sligl, B. (2018). Plastic Not Fantastic. Sierra Magazine, 103(6), [November/December]: 8-9.

Smith, O. (2014). Contemporary adulthood and the night time economy. London. Palgrave.

Smith, O., \& Raymen, T. (2016). Deviant Leisure: A Criminological Perspective. Theoretical Criminology, 22(1), 63-82.

Stafford, R., \& Jones, P. J. (2019). Viewpoint-Ocean plastic pollution: A convenient but distracting truth?. Marine policy, 103 (May), 187-191.

Stiegler, B. (2014). Symbolic misery-volume 1: The hyperindustrial epoch. Cambridge, UK: Polity.

Stone, M. (2020). Carbon emissions are falling sharply due to coronavirus. But not for long. National Geographic, April 3. https://www.nationalgeographic.com/science/2020/04/coronavirus-causing-carbonemissions-to-fall-but-not-for-long/.

Sullivan, L. (2020). How Big Oil Misled The Public Into Believing Plastic Would Be Recycled. National Public Radio (NPR), September 11. Retrieved on February 12, 2021, from https://www.npr.org/2020/ 09/11/897692090/how-big-oil-misled-the-public-into-believing-plastic-would-be-recycled.

Tabuchi, H. (2020). In coronavirus, industry sees chance to undo plastic bag bans. The New York Times, March 26: B5. Published online as "Plastics Industry Sees Chance to Undo Bans on Single-Use Bags" on March 27, 2020, at https://www.nytimes.com/2020/03/26/climate/plastic-bag-ban-virus.html.

Taylor, M. (2017). \$180bn investment in plastic factories feeds global packaging binge. The Guardian, December 26. Retrieved on December 11, 2020, from https://www.theguardian.com/environment/ 2017/dec/26/180bn-investment-in-plastic-factories-feeds-global-packaging-binge.

Thaler, R. H. \& Sunstein, C. R. (2008). Nudge: Improving decisions about health, wealth, and happiness. London. Penguin.

Valenzuela, F., \& Böhm, S. (2017). Against wasted politics: A critique of the circular economy. ephemera: theory \& politics in organization, 17(1), 23-60.

van Doremalen, N., Bushmaker, T., Morris, D.H., Holbrook, M.G., Gamble, A., Williamson, B.N., Tamin, A., Harcourt, J.L., Thornburg, N.J., Gerber, S.I., Lloyd-Smith, J.O., de Wit, E., \& Munster, V.J. (2020). Aerosol and Surface Stability of SARS-CoV-2 as Compared with SARS-CoV-1. The New England Journal of Medicine, 382(16) [April 16]: 1564-1567. https://doi.org/10.1056/NEJMc20049 73. Epub March 17, 2020.

Veblen, T. ([1899] 1965). The Theory of the Leisure Class. New York: Sentry Press.

Zalasiewicz, J., Waters, C. N., Summerhayes, C. P., Wolfe, A. P., Barnosky, A. D., Cearreta, A., ... \& Haff, P. (2017). The Working Group on the Anthropocene: Summary of evidence and interim recommendations. Anthropocene, 19(1), 55-60.

Zarnett, B. (2020). Is Covid-19 the Silver Bullet for a Stable Climate? CSRwire, March 13. Retrieved on February 12, 2021, from https://www.csrwire.com/press_releases/44015-is-covid-19-the-silver-bullet-for-a-stable-climate-.

Zhong, R., \& Zhang, C. (2019). China Chokes on Takeout Plastic. The New York Times, May 28: B1. Published online as "Food Delivery Apps Are Drowing China in Plastic" on May 28, 2019, at https:// www.nytimes.com/2019/05/28/technology/china-food-delivery-trash.html.

Publisher's Note Springer Nature remains neutral with regard to jurisdictional claims in published maps and institutional affiliations. 